\title{
Huzurevinde Yaşayan Yaşlı Bireylerin Düşme Korkusunu Azaltmada Güvenli Hareket ve Yürüme Programının Etkisi
}

\section{The Effects of Safe-Movement and Walking Program on Reducing the Fear of Falling in Elderly Individuals Living in a Nursing Home}

\author{
Gülcan ŞEN ${ }^{\mathrm{a}}$, Saime EROL ${ }^{\mathrm{b}}$
}

ÖZ Amaç: Bu çalışma, huzurevinde yaşayan yaşlı bireylerin düşme korkusunu azaltmada "Güvenli Hareket ve Yürüme Programının” etkisini göstermek amacı ile yürütülmüştür. Gereç ve Yöntem: Çalışma; ön test-son test kontrol gruplu yarı deneysel tasarım ile Kasım 2012-Nisan 2013 tarihleri arasında Aile Sosyal Politikalar Bakanlı̆̆ İstanbul İl Müdürlüğüne bağlı bir huzurevinde yaşayan 73 yaşlı ile gerçekleştirildi. Yaşlılara düş̧e, düşme korkusu, güvenli hareket davranışları, fiziksel aktivite ve yürüyüşü artırmaya yönelik altı haftalık girişim programı uygulandı. Veri toplama aracı olarak, Yaşlı Bilgi Formu, Tinetti Düşmenin Etkisi Ölçeği (TDEÖ), Yaşlılar İçin Düşme Davranışları Ölçeği (YIDDÖ) ve Tinetti Denge ve Yürüme Değerlendirmesi (TDYD) formları kullanıldı. Verilerin değerlendirilmesinde Student t test, Mann-Whitney U test, varyans analizi, Bonferroni test, Friedman test ve Wilcoxon Signed Rank test kullanıldı. Bulgular: Çalışmanın sonucunda deney grubundaki yaşlıların Tinetti Düşmenin Etkisi Ölçeği toplam puanı, YIDDÖ toplam puanı ile Bilişsel Uyum, Hareketlilik, Sakınma, Farkındalık, Pratiklik, Seviye Değişikliği, Telefona Yetişme ve Dikkatlilik alt boyut puanları kontrol grubundan yüksek bulundu. Sonuç: "Güvenli Hareket ve Yürüme Programının" huzurevlerinde yaygınlaştırılması önerilir. Anahtar Kelimeler: Yaşl1, düşme, düşme korkusu, güvenli hareket, yürüme

\begin{abstract}
Aim: The aim of this study is to determine the effects of "Safe-Movement and Walking Program" on fear of falling in the elderly individuals living in a nursing home, using pre-/post-tests and a control-group quasi-experimental research design. Material: The study was carried out with 73 elderly participants who had been living in a rest home operating under the auspices of the Ministry of Family and Social Policies in Istanbul, over the period of November 2012 - April 2013. 6-week intervention program was applied for the elderly individuals oriented to falling, fear of falling, safe-movement behaviours and increasing physical activities and walking. In the study, Elderly Information Form, Tinetti Falls Efficacy Scale (FES), Elderly Falls Behavioural $(\mathrm{FaB})$ Scale and Tinetti Balance and Gait Assessment Form (BGAF) was used as a data collection instrument. Student $t$ test, Mann-Whitney U test, Variance, Bonferroni test, Friedman test and Wilcoxon Signed Rank test was used in evaluation of data. Result: In the study, it was observed that in experimental group, the sub-scale scores of the elderly individuals about their total scores of FES, FaB total score and Cognitive Accommodation, Practicability, Awareness, Avoidance, Activity, Level Change, Catching up Phone calls, Carefulness was higher than in control group. Conclusion: It is recommended that "Safe-Movement and Walking Program" is generalized and more applied in nursing homes.
\end{abstract}

Keywords: elderly, fall, fear of falling, safe movement, walking

\section{Giriş}

Düşmeler yaşlı bireylerde yaralanmaların en belirgin evrensel nedenidir. Tehlikeli düşmelere maruz kalan yaşlıların sayısının artması nedeniyle düşmeler kasıtsız yaralanmaların yol açtığı ölüm ndenlerinin ikinci sirasında yer almaktadır $(1,2)$. Düşme sadece yaşlılara özgü bir durum değildir, fakat yaşlılık dönemindeki düşmeler bireye, aileye ve sağlık çalışanlarına sosyal ve psikolojik olarak olumsuz etkileri nedeniyle giderek önemli bir halk sağlığ problemi haline gelmektedir. Düşme deneyimi yaşamak, kalça kırıkları ve beyin hasarı gibi ciddi yaralanmalara maruz kalmak, engellilik ve ölüm olaylarına tanık olmak yaşlılarda düşme korkusuna yol açmakta ve yaşam kalitesini azaltmaktadır. Düşme korkusunun gelişmesiyle ileriki dönemlerde düşme riski de artmaktadır (1-7). Tinetti ve ark. (1994) düşme korkusunu "temel günlük yaşam aktivitelerini yerine getirirken düşmeden korunmada kendini yetersiz hissetme" olarak tanımlarken çalışmaya katılan yaşl1lar da "düşmenin bir sonucu

\footnotetext{
Geliş Tarihi/Received:18-01-2018/ Kabul Tarihi/Accepted:26-06-2018

${ }^{a}$ Dr. Öğretim Üyesi Karabük Üniversitesi, gulcankar@karabuk.edu.tr, ORCID: 0000-0002-6795-8251

${ }^{b}$ Doçent Doktor Marmara üniversitesi,saimeerol@hotmail.com, ORCID 0000-0001-7752-605X:

Sorumlu yazar /Correspondence: Gülcan ŞEN, gulcankar@karabuk.edu.tr

*Marmara Üniversitesi Sağlık Bilimleri Enstitüsü Halk Sağlığı Hemşireliği Anabilim Dalı Doktora Tezi
} 
olarak gelişen kalıcı korku” olarak tanımlamaktadir (8).

Yaşlılar düşme korkusu yaşadıkları zaman günlük yaşam aktivitelerini daha fazla sınırlandırmaya başlar. Aktiviteler kısıtlandıkça fiziksel güçsüzlük, bağımlılık ve yetersizlik $\operatorname{artar}(5-9)$. Yaşlı düşmemek için hareketlerini kısıtladıkça bir dönem düşmekten kendini korur fakat hareketsizlik nedeni ile yetersizlik gelişir, alt ekstremitelerde kuvvet kaybı artar, günlük yaşam aktivitelerini gerçekleştirme yeteneği azalır ve sosyal çevreden uzaklaşır, böylece düşme riski daha da $\operatorname{artar}(10)$.

Düşme korkusu olan bireylere, yaşadıkları korkuyu azaltıcı yaklaşımlarda bulunulmadığı zaman, korkusu giderek yoğunlaşır ve düşme riski daha da artar (1). Yaşlı kişilerin daha uzun ve daha kaliteli yaşamasını sağlamak ve bakım maliyetlerini azaltmak için düşmelerin ve düşme korkusunun en aza indirilmesi gerekmektedir (7). Düşmeye neden olan hareketleri ve alışkanlıkları belirlemek, güvenli hareket davranışları kazandırmak ve yaşlılarda öz güveni yükseltmek düşme korkusunu azaltmada önerilen girişimlerdir. Birçok çalışma düşmelerin çok faktörlü düşme önleme programları ve egzersiz yardımıyla büyük ölçüde önlenebilir olduğunu göstermektedir $(1,4,6,8)$. Düşmeyi ve düşme korkusunu azaltmaya yönelik geliştirilmesi gereken güvenli hareket davranışları; yaşlıların yürürken, otururken, pozisyon değiştirirken yanlış yapılan ve düşmeye neden olan, bireysel ve çevresel faktörleri fark ederek kontrol altına almasıdır. $\mathrm{Bu}$ da yaşlının kendi hareket hızını kontrol etmesini ve doğru davranışlar sergilemesini sağlar (1,5-7).

Düşme riskini değerlendirmek için yaşlı bireyin sandalyeden kalkma, yürürken dönme, ayağını yerden yukarı kaldırma ve oturma gibi hareketleri uygulama sirasinda izlenmektedir. $\mathrm{Bu}$ aktivitelerin herhangi birinde yaşanan güçlük, düşme riskinin yüksek olduğunu işaret eder. Hemşireler düşmeyi önlemek için yaşl1 bireye, ailesi ve bakım vericilere sağlık hizmeti sağlamalı, düşme riskini ve düşme korkusunu belirli aralıklarla değerlendirmelidir. Hemşire yaşlının duygularını ifade etmesini, kendi kararlarını kendisinin vermesini, becerilerini sergilemesini destekleyerek daha bağımsız hareket etmesine yardımcı olmalıdır $(4,5,9)$.

Yaşl1ların güvenli hareketi için ev içi ve ev dış1 çevre düzenlemeleri yapmak; günlük aktivitelerini ve işlerini kendisinin yapmasını teşvik etmek, sınırları dahilinde beden egzersizleri, yürüyüşleri, solunum egzersizleri, duruş ve postür egzersizleri yapmasını sağlamak önemlidir. Yaşlı bireyin kapasitesine uygun, yaşamının bir parçası olmasını sağlayacak, zorlamayan, kolay ve zevkle yapacağ 1 egzersizler önerilmelidir. Benzer sorunları olan yaşlilar için grup halinde egzersizler ve kısa mesafe yürüyüşleri olumlu sonuçlar verebilir. Aktivitelerin sağlkklı yapılabilmesi için özel yürüyüş ayakkabıları, baston ve yürüteç kullanılması da önerilebilir $(1,4,5,9,10)$.

Tüm bu bilgiler 1şığında bu çalışma, huzurevinde yaşayan yaşlı bireylerin düşme korkusunu azaltmada "Güvenli Hareket ve Yürüme Programının" etkisini göstermek amacı ile yürütülmüştür.

\section{Gereç ve Yöntemler}

Ön test-son test kontrol gruplu yarı deneysel çalışma, Kasım 2012-Nisan 2013 tarihleri arasında İstanbul Aile ve Sosyal Politikalar İl Müdürlügü’ne bağlı bir Huzurevi Yaşlı Bakım ve Rehabilitasyon merkezinde gerçekleştirildi. Çalışma huzurevinde yaşayan 164 bireyden araştırmaya alınma kriterlerine uyan 73 (deney grubu=37, kontrol grubu=36) kişi ile gerçekleştirilmiştir.

\section{Araştırmanın Değişkenleri}

Güvenli Hareket ve Yürüme Programı çalışmanın bağımsız değişkeni; Düşme Korkusu, Tinetti Düşmenin Etkisi Ölçeği (TDEÖ), Yaşlılar İçin Düşme Davranışları Ölçeği (YDDÖ) ve alt boyutları, Tinetti Yürüme ve Denge Değerlendirmesi (TDYD) puanı ve yürüme, denge alt boyutları puan ortalamaları çalışmanın bağımlı değişkenleridir.

\section{Veri Toplama Araçları}

Çalışmanın verileri Yaşlı Bilgi Formu, Standardize Mini Mental Test, Tinetti'nin Düşmenin Etkisi Ölçeği (TDEÖ), Yaşlılar İçin Düşme Davranışları Ölçeği (YIDDÖ) ve Tinetti Yürüme ve Denge Değerlendirmesi (TDYD) formu kullanılarak toplanmıştır.

Standardize Mini Mental Test (SMMT): Mini Mental Test Folstein ve arkadaşları tarafından 1975 'te geliştirilmiştir. Eğitimliler ve eğitimsizler için ayrı olarak düzenlenmiştir. Bilişsel bozuklukların değerlendirilmesinde kullanılmaktadır. Test, toplam 30 puan olup her sorusu bir puan değerindedir. Türkçe uyarlama Güngen tarafından 2002'de yapılmıştır. Türk 
toplumunda hafif demans tanısında geçerli ve güvenilir olduğu, ideal eşik değerin 23/24 olduğunu saptanmıştır (11).

Yaşlı bilgi formu: Yaşlı Bilgi Formu yaşl1ların demografik özelliklerini, düşme durumunu, düşme korkusunu, yürüyüş ve fiziksel aktivite yapma durumunu ve isteğini sorgulayan araştırmacı tarafından literatür doğrultusunda hazırlanan 24 sorudan oluşmaktadir (11-15).

Tinetti'nin Düşmenin Etkisi Ölçeği (TDEÖ): Tinettti ve arkadaşları, kişinin günlük aktivitelerini gerçekleştirirken düşmeyle ilişkili kendi etkinliğini ya da güvenliğini değerlendirmek için TDEÖ'ni 1990 yılında geliştirmişlerdir. Ölçeğin Cronbach alfa katsayıs1 0,71'dir (17). Türkçe geçerlilik ve güvenilirliğini Erdem ve Emel 2004 y1lında yapmıştır, cronbach alpha katsayısı 0,89'dur (16). Çalışmamızda cronbach alpha katsayısı 0,88 olarak bulunmuştur.

Yaşlılar İçin Düşme Davranışları Ölçeği (YİDDÖ): Ölçek 2003 yılında Clemson, Cumming ve Heard tarafindan İngilizce olarak geliştirilmiştir. Öz bildirime dayalı olan ölçek, yaşlıları düşmekten koruyan davranışları, eylemleri ve alışkanlıkları tanımlamak için kullanılmaktadır. Ölçeğin 30 maddesi ve 10 alt boyutu bulunmaktadır. Ölçeğin orijinal dildeki geçerlik güvenirlik cronbach alfa kat sayısı $\alpha=0,84$, alt ölçeklerin alfa katsayısı $\alpha=0,10$ ile $\alpha=0,81$ arasında değişmektedir, test-tekrar test korelasyonu r=0,94'dür $(18,19)$. Ölçeğin Tükçe uyarlaması Uymaz tarafindan gerçekleştirilmiştir. Madde toplam puan korelasyonları 0,23 ile 0,70 arasinda, tesr-retest korelasyonu $\mathrm{r}=0,96$, Cronbach Alfa katsayıs1 $\alpha=0,90$ olarak bulunmuştur. Ölçeğin Türk yaşlı örnekleminde kullanılabilecek geçerli ve güvenilir bir araç olduğu vurgulanmıştır (20). Çalışmamızda ölçeğin cronbach alpha katsayısı 0,84 olarak bulunmuştur.

Tinetti Denge ve Yürüme Değerlendirmesi (TDYD): Ölçek ilk olarak Performance-Oriented Assessment of Mobilitiy Problems in Elderly Patients (POMA) adiyla Mary Tinetti tarafindan 1986 y1lında düşme riski yüksek olan hastalarda değerlendirme yapmak amaciyla geliştirilmiştir. Daha sonra değiştirilerek Tinetti Gait and Balance Assessment adını verilmiştir. Ölçeğin Türkçe geçerlik çalışması dil eşdeğerliği ve kurumsal geçerlilik yöntemleri kullanılarak Ağırcan tarafindan (2009) yapılmıştır ve cronbach alpha katsayısı 0,97 bulunmuştur (21). Çalışmamızda cronbach alpha katsay1s1 0,91'dir. TDYD denge yeteneğini ve yürüyüşü 2 ana başlikta değerlendirmektedir: ilk 9 soru denge, sonraki 7 soru yürüyüş ile ilgilidir. Anket puanının hesaplamasi; ilk 9 maddenin toplamı denge puanını, sonraki 7 maddenin toplamı yürüme puanını, denge ve yürüme puanının toplamı ise toplam puanı vermektedir.

\section{Veri Toplama Yöntemi}

Standardize Mini Mental Test, Yaşlı Bilgi Formu, Tinetti'nin Düşmenin Etkisi Ölçeği (TDEÖ) ve Yaşlılar İçin Düşme Davranışları Ölçeği (YIDDÖ) yaşlllarla yüz yüze görüşülerek dolduruldu. Veri toplamaya yönelik yapılan görüşmenin ardından Tinetti Denge ve Yürüme Değerlendirmesi'ndeki (TDYD) hareketler yaşlılara sırasıyla yaptırılarak, ilgili değerlendirmeler gözlem sonucunda forma kaydedildi.

$A$ ve $C$ blok arasında kura çekilerek $C$ blok deney $(n=43)$ ve A blok kontrol $(n=43)$ grubuna alınd1. Girişim öncesi deney ve kontrol gruplarındaki yaşlılara veri toplama araçları uygulandı (ön test). Daha sonrasında girişim grubundaki yaşlılara altı hafta süren Güvenli Hareket ve Yürüme Programı uyguland. Program biter bitmez deney ve kontrol gruplarından araştırmanın verileri ikinci kez toplandı (son test). Son testin arkasından üç ay süreyle yaşlilara herhangi bir girişim uygulanmadı ve üç ayın sonunda da tekrar veriler toplandı (izlem).

\section{Güvenli Hareket ve Yürüme Programının (GHYP) Uygulanması}

Güvenli hareket ve yürüme programı yaşlı bireylerin düşme korkularını azaltmak, düşmelere karşı kendi önlemlerini almaya alıştırmak ve aktif bir yaşam sürmelerini sağlamak amaciyla literatür doğrultusunda araştırmacı tarafından hazırlandı. Altı haftadan oluşan eğitim programının içeriğinde "düşme ve düşme korkusunun tanımı, gelişimi ve ektileyen faktörler", "güvenli hareket davranışları", "fiziksel aktivite ve yürüyüş yapmanın düşme ve düşme korkusunu azaltmadaki etkisi" konuları yer aldı. Ayrıca güvenli hareket teknikleri gözlem formu, güvenli hareket öz değerlendirme formu, ayak isınma hareketleri gözlem formu, haftalık yürüyüş kayıt formu ve yaşlı bireylerin egzersiz yapma engellerine yönelik görüşme formu kullanıldı. Programda eğitim yöntemi olarak düz anlatım, barkovizyon, soru cevap, vaka örnekleri 
sunumu, gözlem, görüşme demonstrasyon kullanıldı. Eğitim oturumları haftada bir gün ve günde bir saat olarak gerçekleştirildi. Eğitim materyali olarak da Yaşlılar İçin Güvenli Hareket ve Yürüme Programı Eğitim Kitapçı̆̆ı, Güvenli Hareket ve Yürüme Programı Eğitim Afişileri hazırlandı. Eğitimde konuşulanları pekiştirmek, hatırda tutmayı kolaylaştırmak ve bilgilerin davranışa dönüştürmek amacıyla yaşlılarla birebir görüşme ve gözlem yapıldı.

\section{Verilerin Analizi}

Çalışma verilerinin değerlendirilmesinde tanımlayıc1 istatistiksel metodların yanı sira niceliksel verilerin karşılaştırılmasında normal dağılım gösteren parametrelerin iki grup arası karşılaştırmalarında Student $\mathrm{t}$ test, normal dağılım göstermeyen parametrelerin iki grup arası karşılaştırmalarında ise Mann-Whitney $U$ test kullanıldı. Normal dağılım gösteren parametrelerin tekrarlı ölçüm karşılaştırmalarında tekrarlayan ölçümlerde varyans analizi (Repeated Measures Test) grup içi karşılaştırmalarında Bonferroni test kullanıldı. Normal dağılım göstermeyen parametrelerin tekrarlı ölçüm karşılaştırmalarında Friedman Test grup içi karşılaştırmalarında Wilcoxon Signed Rank test kullanıldı. Sonuçlar \%95'lik güven aralığında, anlamlılık $\mathrm{p}<0,05$ ve $\mathrm{p}<0,01$ düzeyinde değerlendirildi.

\section{Araştırmanın Etik Boyutu}

Marmara Üniversitesi Sağlık Bilimleri Enstitüsü Klinik Araştırmalar Ön Değerlendirme Komisyonundan araştırma için etik kurul onay1 (25.11.2011-2), Aile ve Sosyal Politikalar Bakanlığından kurum izni, çalışmaya katılan yaşlılardan sözlü onam alındı. YİDDÖ ölçeği için e-posta yoluyla izin alınd, kontrol grubuna girişim sonrası eğitim verildi.

\section{Bulgular}

Girişim öncesi yapılan değerlendirmede (ön test) cinsiyet, öğrenim düzeyi, son bir yılda düşme olayı yaşama, düzenli yürüyüş yapma durumu, yürüşle ilgili olarak şimdi ve gelecekteki niyeti yönünden deney ve kontrol grubu arasında istatistiksel olarak anlamlı fark saptanmadi $(p>0,05)$.

Yaşlıların düşme korkusu puanlarının deney ve kontrol grubuna göre dağılımı Tablo 1 'de gösterilmiştir. Yapılan analiz sonucu ön test, son test ve izlemde; deney ve kontrol gruplarının düşme korkusu puanları arasında istatistiksel olarak anlamlı farklılık saptanmadı (p>0,05). Deney grubunda; ön test, son test ve izlemde düşme korkusu puanları arasında istatistiksel olarak anlamlı farkl11.k saptand 1 $(\mathrm{p}<0,01)$. İzlemdeki düşme korkusu puanı son test puanına göre anlamlı farklılık göstermezken $(p=0,057 ; p>0,05)$; ön test puanına göre anlamlı düzeyde yüksek bulundu $(\mathrm{p}=0,011$; $\mathrm{p}<0,05)$.

Tinetti Düşmenin Etkisi Ölçeği puan ortalamalarının deney ve kontrol gruplarına göre dağılımı ve ileri analizi Tablo 2'de görülmektedir. Ön test ile son testte, ön test ile izlemde deney ve kontrol gruplarında TDEÖ toplam puanları arasinda istatistiksel olarak anlamlı farklılık görülmedi ( $>0,05)$. Deney grubunda; ön test, son test ve izlemde TDEÖ toplam puanları arasında istatistiksel olarak anlamlı farkl11ık saptandı $(\mathrm{p}<0,05)$. Ön test ile son test ve izlemdeki TDEÖ toplam puanları arasında anlamlı farklılık saptanmadi $(\mathrm{p}=0,710$; $\mathrm{p}=1.000 ; \mathrm{p}>0,05)$.

Yaşlılar İçin Düşme Davranışları Ölçeği toplam puan ortalamalarının deney ve kontrol gruplarına göre dağılımı ve ileri analizi Tablo 3 'de verildi. Deney grubunda; ön test, son test ve izlemdeki YIDDÖ toplam puanları arasında istatistiksel olarak ileri düzeyde anlaml farkl11ı saptand $1(p<0,01)$. Ön test puan1, son test ve izlem puanlarına göre anlamlı düzeyde düşükken ( $p=0,001 ; p=0,001 ; p<0,01)$; son test ve izlem puanları arasinda anlamlı farklılık saptanmadi $(p=0,542 ; p>0,05)$.

Yaşlılar İçin Düşme Davranışları Ölçeği alt boyut puan ortalamalarının ileri analizinde deney grubunda; ön test, son test ve izlemdeki bilişsel uyum, hareketlilik, sakınma, farkındalık, pratiklik, seviye değişikliği, telefona yetişme ve dikkatlilik alt boyut puan ortalamaları arasında istatistiksel olarak ileri düzeyde anlamlı farklılık saptandı $(\mathrm{p}<0,01)$. Acelecilik ve aktivite plan değişikliği alt boyut puan ortalamaları arasında istatistiksel olarak anlamlı farkl11ık görülmedi $(\mathrm{p}>0,05)$.Tinetti Denge ve Yürüme Değerlendirmesi toplam puan1, denge ve yürüme alt boyut puan ortalamalarının ileri analizi Tablo 4'de verilmiştir.

TDYD Denge Puanı; Deney grubunda ön test, son test ve izlemdeki takiplerde denge puanları arasında istatistiksel olarak anlamlı değişim saptanmadi $(\mathrm{p}>0,05)$.

TDYD Yürüme Puanı; Deney grubunda ön test, son test ve izlemdeki yürüme puan ortalamaları arasında istatistiksel olarak ileri düzeyde anlamlı farkl11ı saptand $1(\mathrm{p}<0,05)$. 


\begin{tabular}{|c|c|c|c|c|c|c|}
\hline $\begin{array}{l}\text { Düşme } \\
\text { Korkusu }\end{array}$ & $\begin{array}{l}{ }^{1} \text { Ön Test } \\
\text { Ort } \pm \text { SD }\end{array}$ & $\begin{array}{c}{ }^{2} \text { Son Test } \\
\text { Ort } \pm \text { SD }\end{array}$ & $\begin{array}{c}{ }^{3} \text { İzlem } \\
\text { Ort } \pm \text { SD }\end{array}$ & $\begin{array}{c}\text { Test } \\
\text { değerleri }\end{array}$ & ${ }^{b} p$ & ${ }^{c} p$ \\
\hline $\begin{array}{l}\text { Deney } \\
\text { Grubu } \\
(n=37)\end{array}$ & $4,27 \pm 3,35$ & $4,84 \pm 3,40(3)$ & $5,59 \pm 3,28(6)$ & 14,754 & $0,001 * *$ & $\begin{array}{l}1-2=0,218 \\
1-3=0,011 * \\
2-3=0,057\end{array}$ \\
\hline $\begin{array}{l}\text { Kontrol } \\
\text { Grubu } \\
(n=36)\end{array}$ & $5,47 \pm 3,40(7)$ & $4,83 \pm 3,15(3,5)$ & $5,25 \pm 3,07(5)$ & 1,930 & 0,381 & $\begin{array}{l}1-2=0,147 \\
1-3=0,454 \\
2-3=0,314\end{array}$ \\
\hline $\begin{array}{r}Z \\
{ }^{a} p\end{array}$ & $\begin{array}{c}-1,345 \\
0,179\end{array}$ & $\begin{array}{l}-0,095 \\
0,924\end{array}$ & $\begin{array}{c}-0,478 \\
0,633\end{array}$ & & & \\
\hline${ }^{a} M a n n-W h$ & ney U test & ${ }^{b}$ Friedman' & & coxon Test & & \\
\hline
\end{tabular}

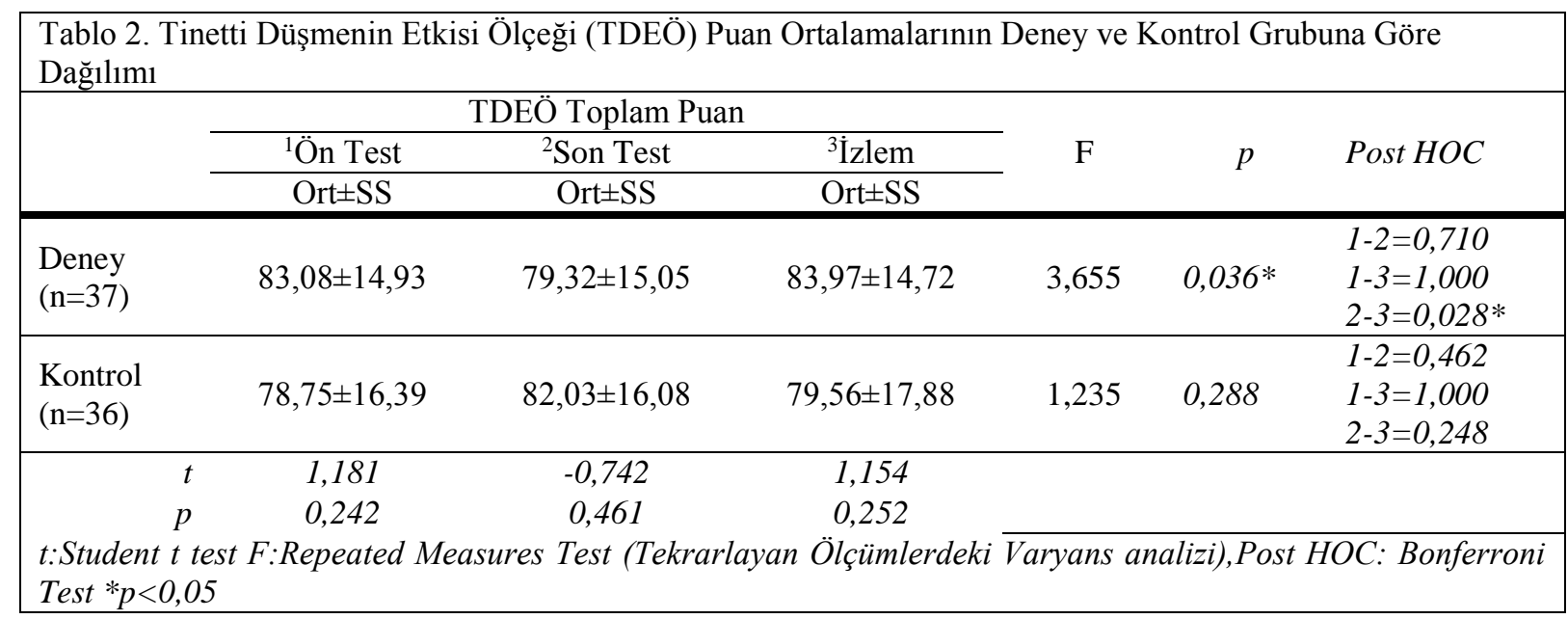

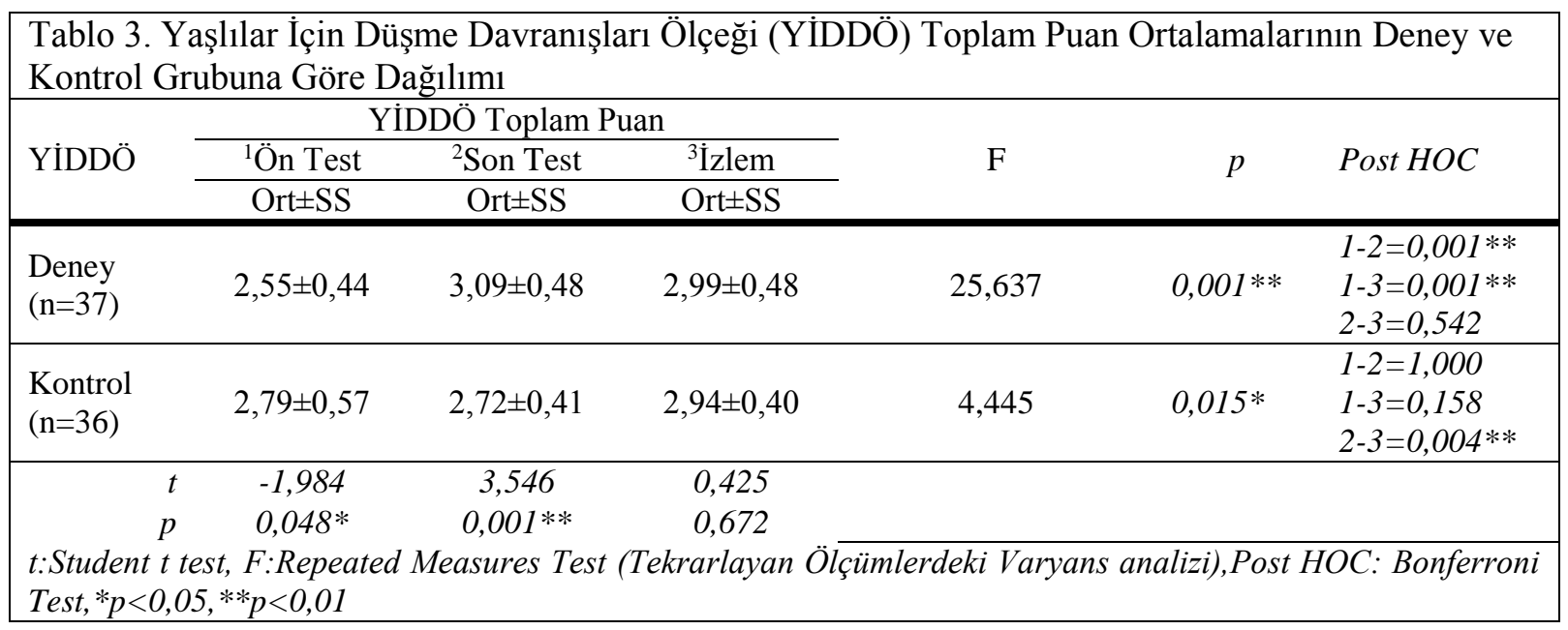




\begin{tabular}{|c|c|c|c|c|c|c|c|}
\hline \multicolumn{8}{|c|}{$\begin{array}{l}\text { Tablo 4. Tinetti Denge ve Yürüme Değerlendirmesi (TDYD) Toplam Puanı, Denge ve Yürüme A } \\
\text { Boyut Puan Ortalamalarının Deney ve Kontrol Grubuna Göre Dağılımı }\end{array}$} \\
\hline \multirow{2}{*}{\multicolumn{2}{|c|}{$\begin{array}{l}\text { Tinetti Denge ve } \\
\text { Yürüme } \\
\text { Değerlendirmesi }\end{array}$}} & ${ }^{1}$ Ön Test & ${ }^{2}$ Son Test & ${ }^{3} \mathbf{I}$ Izlem & \multirow[b]{2}{*}{$\mathbf{F}$} & \multirow[b]{2}{*}{$p$} & \multirow[b]{2}{*}{ Post HOC } \\
\hline & & Ort \pm SS & Ort \pm SS & Ort \pm SS & & & \\
\hline \multirow{4}{*}{ 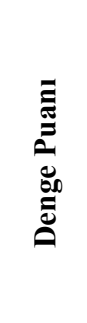 } & $\begin{array}{l}\text { Deney } \\
(\mathrm{n}=37)\end{array}$ & $12,19 \pm 3,75$ & $13,00 \pm 3,99$ & $12,70 \pm 4,59$ & 1,696 & 0,191 & $\begin{array}{l}1-2=0,170 \\
1-3=0,988 \\
2-3=1,000\end{array}$ \\
\hline & $\begin{array}{r}\text { Kontrol } \\
(n=36) \\
\end{array}$ & $12,06 \pm 4,39$ & $12,06 \pm 4,09$ & $10,92 \pm 5,06$ & 5,585 & $0,008 * *$ & $\begin{array}{l}1-2=1,000 \\
1-3=0,429 \\
\mathbf{2 - 3}=0,006 * *\end{array}$ \\
\hline & $t$ & 0,140 & 0,999 & 1,581 & & & \\
\hline & $p$ & 0,889 & 0,321 & 0,118 & & & \\
\hline \multirow{4}{*}{ 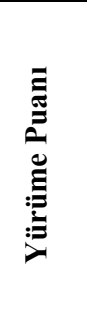 } & $\begin{array}{l}\text { Deney } \\
(\mathbf{n}=37)\end{array}$ & $8,84 \pm 3,05$ & $8,86 \pm 2,89$ & $9,89 \pm 3,15$ & 4,539 & $0,025^{*}$ & $\begin{array}{l}1-2=1,000 \\
1-3=0,120 \\
2-3=0,002 * *\end{array}$ \\
\hline & $\begin{array}{r}\text { Kontrol } \\
(\mathbf{n}=36)\end{array}$ & $9,19 \pm 2,66$ & $9,47 \pm 2,50$ & $9,06 \pm 2,70$ & 0,652 & 0,501 & $\begin{array}{l}1-2=1,000 \\
1-3=1,000 \\
2-3=0,413\end{array}$ \\
\hline & $t$ & $-0,532$ & $-0,959$ & 1,215 & & & \\
\hline & $p$ & 0,597 & 0,341 & 0,228 & & & \\
\hline \multirow{4}{*}{ 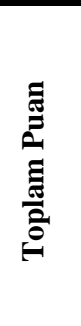 } & $\begin{array}{l}\text { Deney } \\
(\mathbf{n}=37)\end{array}$ & $20,95 \pm 6,52$ & $21,86 \pm 6,61$ & $22,54 \pm 7,43$ & 2,483 & 0,108 & $\begin{array}{l}1-2=0,613 \\
1-3=0,245 \\
2-3=0,557\end{array}$ \\
\hline & $\begin{array}{r}\text { Kontrol } \\
(\mathbf{n}=36)\end{array}$ & $21,19 \pm 6,84$ & $21,58 \pm 6,26$ & $19,97 \pm 7,36$ & $5 ., 657$ & $0,008 * *$ & $\begin{array}{l}1-2=1,000 \\
1-3=0,830 \\
\mathbf{2 - 3}=0,007 * *\end{array}$ \\
\hline & $t$ & $-0,159$ & 0,187 & 1,484 & & & \\
\hline & $p$ & 0,874 & 0,852 & 0,142 & & & \\
\hline
\end{tabular}

t:Student $t$ test F:Repeated Measures Test (Tekrarlayan Ölçümlerdeki Varyans analizi),Post HOC: Bonferroni Test $* p<0,05$, **p $<0,01$

TDYD Toplam Puanı; Deney grubunda ön test, son test ve izlemdeki puan ortalamaları arasında istatistiksel olarak anlamlı farklılık saptanmadi $(\mathrm{p}>0,05)$.

\section{Tartışma}

$\mathrm{Bu}$ çalışmada, huzurevinde yaşayan 65 yaş ve üzeri bireylerin düşme korkusunu azaltmada güvenli hareket ve yürüme programının etkisi değerlendirilmiştir. Çalışmanın sonuçları, güvenli hareket davranışlarını geliştirmede, fiziksel aktivite toleransinı ve niyetini artırmada, yürüme yeteneğini geliştirmede Güvenli Hareket ve Yürüme Programının (GHYP) etkili olduğunu göstermiştir.

Bu çalışmada, düşme korkusunu 1'den (en az korku) 10'a (en çok korku) kadar puanlamalarını isteyerek elde ettiğimiz düşme korkusu puanı ön test, son test ve izlemde; deney ve kontrol grupları arasında istatistiksel olarak anlamlı fark bulunmadi. Ayrica deney grubunda, izlemdeki düşme korkusu puanı ön testteki düşme korkusu puanına göre anlamlı düzeyde yüksek bulundu (Tablo 1). Literatürde, yapılan girişimler sonucu düşme korkusunda azalma olduğu ya da düşme korkusunun değişmediği gösterilmiştir. Düşme önleme programları ile düşme korkusunun azaldığını gösteren araştırma kanıtlarının $(22,23)$ yanı sıra bu girişimlerin düşme korkusuna etkisinin olmadığını gösteren çalışmalar da bulunmaktadır (24). Girişim sonucu düşme korkusunun arttığını gösteren çalışmalara rastlanmamıştır. Güvenli hareket ve yürüme programı kapsamında yapılan görüşmelerde yaşlıların kullandığ 1 "düşüyorum ama kalkıyorum bir şey olmuyor ki" "çocuklar düşe kalka büyür, yaşlılar düşe kalka ölür" gibi ifadelerden düşmeler ve zararları konusunda yeteri kadar bilince sahip olmadıkları ya da bu durumu kabullendikleri düşünülmüş̧ür. Düşme korkusundaki anlamlı artış, yapılan girişimler sonucunda düşme riskleri ve sonuçları konusunda farkındalıklarının artmasına bağlan- 
mıştır. Bu çalışmada düşme korkusunun azaltılmasında daha çok bilişsel ve davranışsal girişimlere yer verilmiştir. Program süresinde oluşan fikirler doğrultusunda bu çalışma grubunda düşme korkusunu azaltmak için tutuma yönelik uygulamalara daha fazla yer verilmesi gerektiği kanısına varılmıştır.

Tinettti ve arkadaşları düşme korkusunu "temel günlük yaşam aktivitelerini yerine getirirken düşmeden korunmada kendini yetersiz hissetme" olarak tanımlamışlardır. TDEÖ'den alınan puan arttıkça, düşme korkusu azalmaktadır (17). Çalışmamızda deney grubunun TDEÖ puan ortalamaları 79,32 ile 83,97 arasinda bulundu (Tablo 2). Bu bize grubun aktivitelerini yaparken kendilerini güvende hissettiklerini ve düşme risklerinin düşük, düşme korkularının da düşük olduğunu göstermektedir. Deney grubuna yapılan GHYP'1 TDEÖ puanını izlemde anlamlı derecede artırmıştır. TDEÖ puanının artması düşme korkusunun ve düşme riskinin azaldığını gösterir. Ancak bu artış sadece izlemde görüldügü için yeterli görülmemektedir. Çünkü asıl artış girişim sonrası puanlarda olması beklenirken, bu dönemde tam aksine bir düşüş görülmektedir. Düşme korkusunun izlemde anlamlı olarak azalması literatür bilgisi ile parelellik göstermesine rağmen düşme korkusunu azaltmada istediğimiz kadar katk1 sağlamamıştır. Düşme korkusuna yönelik eğitimlerin ve girişimlerin sürekliliğinin sağlanması düşme korkusunun azalmasında etkili olabileceği düşünülmektedir.

Düşme davranışları ölçeğine göre bireylerde fiziksel fonksiyonların azalması gibi bir risk varsa koruyucu davranışları uygulamayan yaşlılar düşme riski altındadır. Koruyucu davranışlar kişilerin bilinçli ve istekli olarak yaptığı ve yapmaktan kaçındığı eylemleri ve alışkanlıklardır. Yaşlıların günlük aktiviteleri sırasında düşmelerden kendilerini korumak için sergiledikleri davranışları tanılamaya yönelik olan araç öz-bildirime ya da görüşme yöntemine uygun şekilde tasarlanmıştır ve yaşlı bireylerin kendi davranışları konusundaki algıları ile sınırlıdır. Ölçekten alınan yüksek puanlar bireyin düşmeye ilişkin güvenli / koruyucu davranışlarını, düşük puanlar ise riskli davranışlarını gösterir. ${ }^{18-20}$ YİDDÖ’nin Bilişsel Uyum alt boyutu düşünme ve planlama ile ilgili davranışları açıklar. Hareketlilik alt boyutu destekleyici, koruyucu yöntemler ve denge açısından çevrenin değerlendirmesini yapan/yapmayanları tanımlar. Sakınma alt boyutu kişinin düşme riskinden sakındığ 1 davranışlarını tanımlar. Farkındalık alt boyutu bireyin trafik gibi diş çevresinde farkında olduğu tehlikeleri, acelecilik alt boyutu bireylerin günlük yaşamlarında bir şeyleri hızlı yapmaktan kaçınmalarını ve hızlı yapmadığ şeyleri tanımlar. Pratiklik alt boyutu bireyin önceden düşme konusunda sezdiği tehlikeleri ve planlamalarını, seviye değişikliği alt boyutu bireylerin daha zorlu aktivitelerle başa çıkmasını tanımlar. Aktivite planında değişiklik alt boyutu bilhassa rüzgârlı günlerde dişarı çıkmay1, telefona yetişme alt boyutu telefon gibi birtakım eşyalara erişmeye çalışırken düşmemek adına özen göstermek ya da göstermemeyi, dikkatlilik alt boyutu dikkatli olmayı tanımlar (18-20).

Uysal ve arkadaşları (2006) da yaptıkları araştırmalarında yaşlıların "ayakkabılarını/ terliklerini doğru bir şekilde giyme ", "evde dikkatli hareket etme", "evde bir şeyler yaparken dikkatli davranma" maddelerinden yüksek puan alarak güvenli davranışlar içinde bulunduğunu; "yüksekteki eşyaları almak için, merdiven veya sandalye üzerine çıkma" ve "telefona/kapıya cevap vermek için hızlı hareket etme" maddelerinden düşük puan alarak her an bir düşme olayıyla karşı karşıya kalma risklerinin yüksek olduğunu göstermişlerdir (22). Uymaz'ın (2012) yaptığı çalışmada huzurevinde kalan yaşlı bireylerin düşme davranışları puan ortalamaları girişim öncesine göre girişim sonrasında istatistiksel olarak anlamlı artmıştır (23). Düşme davranışları ölçeğinin alt boyut puan ortalamaları düşme önleme program1 öncesi ve sonras1 karşılaştırıldığında, sakınma alt boyutu dışında kalan diğer alt boyutların puan ortalamaları arasında ileri düzeyde anlamlı fark olduğu bulunmuştur. Çalışmamızda da Uymaz'ın bulgularına paralel olarak YIDDÖ puan ortalamalar1 ön testte $2,55 \pm 0,44$, son testte $3,09 \pm 0,48$, izlemde ise $2,99 \pm 0,48$ olup fark ileri düzeyde anlamlı bulunmuştur (Tablo 3) (23). Yaşl1lar düşmelerden koruyucu güvenli davranışları girișim öncesi "ara sıra" gösterirken girişim sonrasında "genellikle" göstermektedirler. Ayrıca YİDDÖ bilişsel uyum, hareketlilik, sakınma, farkındalık, pratiklik, seviye değişikliği, telefona yetişme ve dikkatlilik alt boyut puan ortalamalarındaki artış da ileri düzeyde anlamlı bulunmuştur. Acelecilik ve aktivite plan değişikliği alt 
boyutlarında ise sonuçlar anlamlı bulunmamıştır.

GHYP genel anlamda yaşlıların düşmekten koruyucu davranışlarını geliştirmede ve sürdürmede etkili olmuştur. Program süresince yaşlılarla yapılan görüşmelerde en sıkıntılı oldukları davranışların günlük yaşam aktiviteleri sirasında ani hareketler yapmaya meyilli olmak ve aceleci davranmak olduğu görülmüştür. Soğuk, karlı ve yağışl1 günlerde dişarıya çıkmaktan kesinlikle çekinmediklerini belirtenlerin sayısı da fazladır. Bu yüzden GHYP'ndaki aktiviteler yaşlıların acelecilik ve aktivite plan değişikliği alt boyut puan ortalamalarında anlamlı değişiklik gerçekleştirmek için yeterli olmamıştır.

Çalışmamızda TDYD toplam puan ortalamalar1 ön testte $20,95 \pm 6,52$, son testte $21,86 \pm 6,61$, izlemde de $22,54 \pm 7,43$ bulunmuştur. Ağırcan (2009) ölçeğin geçerlik ve güvenirliğini yaptığı çalışmada, ölçekten alınan toplam puan 18 ve altı ise düşme riskinin yüksek, 19-24 puan ise düşme riskinin orta derece, 24 ve üstü ise düşme riskinin düşük olduğunu gösterir (21). Çalıșmamızda da yaşlıların ölçekten aldıkları toplam puan doğrultusunda düşme riski orta derecede bulundu (Tablo 4). Soyuer ve arkadaşlarının (2012) yaşlılarda yaptığı bir çalışmada TDYD toplam puan ortalaması 28 olarak bulunmuş ve düşme riski düşük olarak değerlendirilmiştir (25). Gemalmaz ve arkadaşları (2004) huzurevindeki yaşlıların TDYD puan ortalamalarını 19,51 bulmuş ve yüksek riskli grup olarak değerlendirmiştir (26). Tinetti ve arkadaşları (1994) düşme korkusu olan ve düşen bireylerin önemli derecede denge ve yürüme bozukluklarına sahip olduklarını belirtmişlerdir (8).

TDYD toplam puanında ve alt boyutu olan denge puan ortalamalarında, deney kontrol grupları arasında anlamlı fark görülmemiştir. Sadece yürüme alt boyut puan ortalamalarında deney ve kontrol grupları arasinda anlaml fark bulunmaktadır (Tablo 4). Yağcı ve arkadaşları (2003) yaptıkları girişim sonucunda denge puanlarında anlamlı artış elde etmiştir (27). İsveç'de yapılan randomize kontrollü bir çalışmada denge grup eğitimi uygulanarak TDYD, düşme korkusunda ve istenilen hızdaritimde yürümede anlamlı fark saptanmıştır (28). Avusturalya'da yapılan bir diğer çalışmada toplum temelli grup eğitimi uygulanarak dengede anlamlı fark bulunmuş fakat yürüme hızında anlamlı fark elde edilememiştir (29).
Yine benzer şekilde Zhang ve arkadaşları (2006) tai chi egzersizi sonrasında denge ve esneklikte anlamlı fark elde etmiş, yürümede ise anlamlı fark olmamıştır (30). GHYP içeriği TDYD toplam puanında anlamlı değişiklik sağlayarak, düşme riskini azaltmada etkili olmuştur. Programın içeriğinde denge gelişimden çok yürüme yeteneklerinin artırılması hedeflendiği için denge puanında anlamlı değişiklik sağlanamamıştır. Programda denge gelişimine daha fazla yer verilmesi gerekmektedir.

\section{Sonuç ve Öneriler}

Sonuç olarak deney grubunda güvenli hareket ve yürüme programı sonrasında; Yaşlılarda düşme korkusunun azalması hedeflenirken, anlamlı olarak artmıştır. Yaşlıların düşmeye karş1 kendilerini güvende hissetmelerinde anlamlı fark sağlanmamıştır. Yaşlılar İçin Düşme Davranışları Ölçeği toplam puanı, bilişsel uyum, hareketlilik, sakınma, farkındalık, pratiklik, seviye değişikliği, telefona yetişme, dikkatlilik alt boyut puan ortalamaları anlamlı olarak artmıș, acelecilik alt boyutunda anlamlı olarak artış olmamıştır. TDYD toplam puanı ve denge alt boyutu puanında anlamlı olarak artış olmamıştır.

Çalışmanın sonuçları doğrultusunda; huzurevlerinde, yaşl1lara yönelik güvenli hareket ve yürüme programına farklı boyutlar da eklenerek (kas ve kemilkleri güçlendirmeye yönelik ağırlık çalışması vb.) uygulanması önerilir.

Düşme korkusunu azaltmak için düşme korkusuna yönelik derinlemesine görüşmeler yapılması, korkuyla başetme yollarının öğretilmesi önerilir.

\section{Kaynaklar}

1. Olij B F, Erasmus V, Kuiper J I, Van Zoest F, Van Beecka E F, Polinder S. Falls Prevention Activities Among CommunityDwelling Elderly in The Netherlands: A Delphi Study. International Journal of the Care of the Injured, 2017, 48 (9), 2017-2021.

2. Kaya T, Karatepe AG, Avcı A, Günaydın R. Yaşlılarda Düşme Korkusu ve Düşmeye Karş1 Yetkinlik [Fear of Falling and Falls Efficacy in The Elderly]. Turkish Nursing of Geriatrics, 2012. 15 (3) 260-265.

3. Eyigör S. Düşmelere Yaklaşım [Approach to falls]. Ege T1p Dergisi. 2012, 51 Ek Say1, syf.43-51. 
4. Greenberg S A, Sullivan-Marx E, Sommers M S, Chittams J, Cacchione P Z. Measuring fear of falling among high-risk, urban, community-dwelling older adults. Geriatric Nursing, 2016, 37 (6), 489-495.

5. Whipple M O, Hamel A V, Talley K M. Fear of Falling Among Community-Dwelling Older Adults: A Scoping Review to İdentify Effective Evidence-Based İnterventions. Geriatric Nursing, 2017,1-8.

6. Thiamwong L, Suwanno J. Fear of Falling and Related Factors in a Community-Based Study of People 60 Years and Older in Thailand. International Journal of Gerontology, 2017, 11, 80-84.

7. Glover L, Kinsey D, Clappison D J, Gardiner E, Jomeen J. "I Never Thought I Could Do That...": Findings From an Alexander Technique Pilot Group for Older People With a Fear of Falling. 2017, European Journal Of Integrative Medicine, 17, 79-85.

8. Tinetti ME, Baker DI, Gail CS, Claus EB, Garrett P, Gottschalk M, Koch ML, Trainor K, Horwitz RI. A Multifactorial Intervention to Reduce The Risk of Falling Among Elderly People Living in The Community. The New England Journal Of Medicine, 1994. Volume 331, number 13, 821-827.

9. Atay E, Akdeniz M. Yaşlilarda Düşme, Düşme Korkusu ve Bedensel Etkinlik [Falls in Elderly, Fear of Falling and Physical Activity]. GeroFam, 2010. 2(1): 11-28.

10. Lach HW. Incidence and Risk Factors for Developing Fear of Falling in Older Adults. Public Health Nursing. 2005, 22 (1), 45-52.

11. Güngen C, Ertan T, Eker E, Yaşar R, Engin F. Standardize Mini Mental Test'in Türk Toplumunda Hafif Demans Tanısinda Geçerlik ve Güvenilirliği [Reliability and Validity of The Standardized Mini Mental State Examination in The Diagnosis of Mild Dementia in Turkish Population]. Türk Psikiyatri Dergisi, 2002, 13, 273-281.

12. Kaya Ç A, Kırımlı E, Kalaça Ç, Çifçili S, Ünalan P C, Kalaça S. Huzurevlerinde Kalan Yaşlılarda Düşme İnsidansı ve İlişkili Faktörler [The Incidence of Falls and Related Factors in The Elderly Living In Residential Homes]. Türk Geriatri Dergisi, 2012. 15 (1) 40-46.

13. Bıyıklı K. Huzurevinde Yaşayan Bir Grup Yaşlıda Düşme İle İlişsili Faktörler, Demografik Özellikler, Sağlık Sorunları ve Kullanılan İlaçlar [Factors Related to Falls in a sample of Older People Living in Rest Home; Demographic characteristics, Health problems and Use of Medicines]. İstanbul Üniversitesi Sağlik Bilimleri Enstitüsü, Halk Sağlığı Hemşireliği Ana Bilim Dalı, Yüksek Lisans Tezi, İstanbul, 2006.

14. Yörük S. Balıkesir Üniversitesi T1p Fakültesi Dahiliye Kliniğinde Yatan Yaşlılarda Düşme Korkusu ve Etkileyen Faktörlerin İncelenmesi [Evaluation of The Fear of Falling and the Effective Factors in Old People Staying in Balýkesir State Hospital Internal Medicine Service]. Adnan Menderes Üniversitesi Tip Fakültesi Dergisi, 2012, 13(2): 25-29.

15. Toraman A, Yıldırım N Ü. Düşme İle İlişkili ve İliş̧kisiz Hastalığı Olan Yaşlı Bireylerde Düşme Riski ve Fiziksel Uygunluk [Fall Risk and Physical Fitness in The Elderly With Fall Related Conditions or Unrelated Diseases]. Türk Geriatri Dergisi, 2010. 13 (2) $105-110$.

16. Erdem M, Emel F H. Yaşlilarda Mobilite Düzeyi ve Düşme Korkusu [Mobility Levels and Fear of Falling in The Elderly]. Atatürk Üniversitesi Hemşirelik Yüksekokulu Dergisi, 2004. 7 (1).

17. Tinetti M E, Richman D, Powell L. Falls efficacy as a measure of fear of falling. Journal of Gerontology, 1990. 45 (6),239243.

18. Clemson L, Cumming G R, Heard R. Validating the Falls Behavioral (FaB) Scale for Older People: A Rash analysis. Disability and Rehabilitation, 2008. 30 (7): 498-506.

19. Clemson L, Cumming R, Kendig H, Swann M, Heard R, Taylor K. The Effectiveness of a Community-Based Program for Reducing The Incidence of Falls in The Elderly: A Randomised Trial. Journal of American Geriatrics, 2004. 52:1487-1494.

20. Uymaz PE, Nahcivan N. Yaşlılar İçin Düşme Davranışları Ölçeğinin Geçerlik ve Güvenirliği [Reliability and Validity of Fall Behavioral Scale for Older People]. Florence Nightingale Hemşirelik Dergisi, 2013. 21 (1), Şubat, 22-32.

21. Ağırcan D. Tinetti Balance and Gait Assessment'ın (Tinetti Denge ve Yürüme Değerlendirmesi) Türkçeye Uyarlanmas1, Geçerlilik ve Güvenilirliği [Validity and Reliability of Turkish Version of Tinetti Balance and Gait Assessment]. Pamukkale Üniversitesi, Sağlık Bilimleri Enstitüsü, 
Fizik Tedavi ve Rehabilitasyon Anabilim Dalı, Yüksek Lisans Tezi, Denizli, 2009.

22. Donat H, Özcan A. Comparison of The Effectiveness of Two Programmes on Older Adults at Risk of Falling: Unsupervised Home Exercise and Supervised Group Exercise. Clinical Rehabilitation, 2007. 21: 273-283.

23. Uymaz PE. Huzurevinde yaşayan yaşlilara uygulanan düşme önleme programının değerlendirilmesi [Evaluation of Fall Prevention Program in Elderly Nursing Home Residents]. İstanbul Üniversitesi Sağlık Bilimleri Enstitüsü, Halk Sağlığ Hemşireliği Anabilim Dalı, Halk Sağlı̆̆ Hemşireliği Programı Doktora Tezi, 2012, İstanbul.

24. Uysal A, Ardahan M, Ergül Ş. Evde Yaşayan Yaşlilarda Düşme Risklerinin Belirlenmesi [Determination of The Falling Risks of Elderly Living at Home]. Türk Geriatri Dergisi, 2006. 9 (2): 75-80

25. Soyuer F, Şenol V, Elmalı F. Huzurevinde Kalan 65 Yaş ve Üstündeki Bireylerin Fiziksel Aktivite, Denge ve Mobilite Fonksiyonları [Physical Activity, Balance and Mobility Functions of 65 and over Older People Living at Rest Home]. Van Tip Dergisi, 2012. 19(3): 116-121.

26. Gemalmaz A, Dişçigil G, Başak O. Huzurevi Sakinlerinin Yürüme ve Denge Durumlarının Değerlendirilmesi [Evaluation of The Balance and Gait Status in Nursing Home Residents]. Türk Geriatri Dergisi, 2004. 7 (1): 41-44.

27. Yağcı N, Gürsoy S, Cavlak U, Er S, Koçaker A. Huzurevinde Yaşayan Yaşlilarda 6 Haftalık Yürüme Programının Fiziksel Performansa Etkileri [The Effects of 6-Week Walking Program on Physical Performance in Institutionalized Elderly People]. Fizyoterapi Rehabilitasyon, 2003. 14(3); 121-125.

28. Halvarsson A, Olsson E, Faren E, Pettersson A, Stahle A. Effect of New, İndividually Adjusted, Proggressive Balance Group Training for Elderly People With Fear of Falling and Tend to Fall: A Randomize Controlled Trial. Clinical Rehabilitation, 2011. 25 (11), 1021-1031.

29. Barnett A, Smith B, Lord SR, Williams A, Baumand A. Community-Based Group Exercise Improves Balance and Reduces Falls in at-risk Older People: A Randomised Controlled Trial. Age and Ageing, 2003. 32 (4), 407-414.

30. Zhang JG, Ishikawa-Takata K, Yamazaki H, Morita T, Ohta T. The Effects of Tai Chi Chuan on Physiological Function and Fear of Falling in The Less Robuts elderly: An Intervention Study for Preventing Falls. Archieves of Gerontology and Geriatrics, 2006. 42: 107-116. 